\title{
Contemporary state and perspectives of scientific maintenance of food-processing industry of Ukraine
}

\author{
Sychevskiy M. ${ }^{1}$, Khomichak L. ${ }^{2}$, Romanchuk I. ${ }^{3}$
}

Institute of food resources of NAAS, Ye. Sverstiuk Str., 4, Kyiv, 02002, Ukraine; e-mail: ${ }^{1}$ dir@ipr.net.ua, 2Ihomichak@ukr.net, ${ }^{3}$ dairy@ipr.net.ua

The purpose. To analyze perspective directions of creation competitive technologies of products of nutritional and technical purposes. Methods. Analytical researches of fact materials describing state of nutritional branch and trends in its development. Results. On the basis of analysis of actual problems of nutritional branch the priority tasks providing scientific accompaniment of development of nutritional branch are specified: development of traditional technologies for raising competitiveness of domestic foodstuff; application of bioactive ingredients in technologies of products of improving purpose; raise of efficiency of application of microbial enzymatic systems in biogeotechnology of the fermented products; substantiation of rational schemes of processing agricultural raw material in products of nutritional and technical purposes; application of modern quality monitoring of processes and parameters of products according to international standards. Strategic direction in solution of problems of nutritional branch is creation of waste-free technologies of processing agricultural raw material and ecologization of production. Raise of depth of processing agricultural raw material and diversification of production on the basis of innovative solutions promote raise of profitableness of factories of recycling branch. Basic scientific results for the last three years and implemented innovative developments are brought. Conclusions. Efficiency of domestic nutritional branch is determined by interaction of science and business. Legislative and normative baselines providing functioning of food complex on the basis of fuller utilization of opportunities of domestic production for satisfaction of inner needs, substitution of imported food, increase in export of share of products with high extent of processing demand the further perfection.

Key words: nutritional and process industry, technology, innovations, scientific development.

https://doi.org/10.31073/agrovisnyk201811-23

Formulation of the problem. Development and improvement of food technologies, management of their quality and safety are important aspects of the functioning of the food market, efficient use of raw materials resources and meeting the population's nutritional needs. To date, the scientific justification of technologies for the production and processing of agricultural products and the creation of a scientific base on food safety and quality are topical tasks of food science. The conceptual principle of improving the food supply and the quality of nutrition of the population consists in the introduction of modern technologies and equipment that exclude the possibility of bacterial, chemical and physical contamination, as well as the improvement of technologies for processing and storing food raw materials in order to achieve maximum preservation of its quality and reduce losses of biological value. Expansion of scientific knowledge about rational and balanced nutrition, new data on the properties of food products and the influence of individual ingredients induce not only the development of new, but also the improvement of traditional technologies for food production.

Methods. Analytical research of factual materials concerning the state of the food industry and trends of its developments.

Results and discussions. It is confirmed by the analysis of the current state of the food and processing industries of the Ukrainian economy that agricultural products with a relatively low share of added value are predominant in exports. The need for scientific research aimed at creating advanced technologies for the production of food products of improved quality and safety based on deep processing of agricultural raw materials is obvious, which ensures the comprehensive use of its components, intensification of production processes and contributes to the competitiveness of the national economy on the basis of innovative and investment development. 
The assessment of the scientific potential of the Institute of Food Resources attests to the possibility of providing scientific support for the main branches of the food industry. Such priority areas of activity are meat, dairy, sugar, alcohol and bakery industries.

The real problems of the food industry have been analyzed and the main tasks that are being realized within the framework of the scientific research program of the NAAS for 2016-2020 "Metabolism of agricultural raw materials in food and technical products in the process of forming the national food system" are defined. Priority tasks are:

- improvement of traditional technologies to increase the competitiveness of domestic food products;

- use of bioactive components in the technologies of balanced foods to ensure their high nutritional and biological value;

- increasing the effectiveness of the use of microbial enzyme systems in the production of fermented foods;

- substantiation of rational schemes for processing agricultural raw materials into food and technical products;

- application of modern methods for controlling the performance of products in accordance with international standards in order to confirm the compliance of products with the established requirements.

The qualification level of scientific workers and the existing experimental base of the institution are of particular importance for ensuring the implementation of fundamental and applied research at the proper level.

Among the modern trends in the development of the food industry, growth in both demand and supply for the products can be observed these obtaining such traits as naturalness, presence of nutrients in the formulation, dietary properties, and the like. Thus, the creation of products with high food and biological value, including those enriched with macro- and micronutrients, is aimed at ensuring public health and preventing diseases associated with nutritional disorders. Natural nutritional compounds introduced into the food product must satisfy certain dietary needs and ensure the normal development of tissues of the human body. A healthy lifestyle has been becoming more popular in the modern world. For their own health, people are ready to change their diet, while changing their food addictions, in turn, affects the food market. Intensive scientific developments in the field of food technologies make it possible to predict the increase in demand for such products.

In order to improve the nutritional and biological value of meat products, to preserve the most valuable components of raw materials, to achieve the balance of the fatty acid composition and to compensate for the shortage of a number of macro- and micronutrients, new functional foods have been developed based on combining and optimizing the compositions by incorporating functional ingredients into their formulations [1]. Already in the near future manufacturing traditional food products enriched with essential micronutrients, giving them functional properties can be started at the enterprises of food and processing industry. Theses are: bread, bakery, flour confectionery products with the addition of vitamins $B, A, E$, calcium, iron, iodine, selenium, etc.; milk and milk products with multivitamin complexes, lactobacilli; assortment of sugarcontaining products with functional ingredients. Considering the extremely important role of health food in the system of environmental protection of the population of Ukraine, the technologies of preliminary preparation of plant and animal raw materials for obtaining a wide range of functional products have been developed. The technology of using fructan of an inulin-containing group (oligofructose, inulin and high-molecular inulin) in the production of various food products has been developed. Their classification is proposed depending on the physicochemical properties, conformational structure and molecular weight. It is proved that the addition of fructan improves the consistency of milk products (yoghurt, sour cream), the shelf life of butter is extended and the functional properties of these products are enhanced [2].

Many years of experience gained in the design of technological equipment for the dairy industry, allow for the improvement of existing devices taking into account the needs of the industry. Based on studies of the thermal-physical properties of milk fat substitutes and their compositions with milk fat in the zone of phase transformations in the temperature range from minus 80 to plus $90{ }^{\circ} \mathrm{C}$, a relationship was established between the change in heat capacity and the free volume of systems, and their specific heat was determined. Based on the concept of the free volume of non-Newtonian fluids as a universal viscosity criterion, the viscosity of milk fat substitutes and mixtures is calculated, this being a necessary component of 
the calculations of heat exchangers for butter and fat production [3]. The influence of technological regimes of the process of obtaining cheese grain on the rheological characteristics of cheese mass was scientifically substantiated in the production of hard cheeses in the cheese making machines of Ya5-OSZh mark, the design of cheese-making equipment was developed [4].

The introduction of effective biotechnologies is associated, first of all, with the use of biologically active strains of microorganisms that provide the necessary direction of biochemical transformations in raw materials, affect the flow and duration of technological processes. An osmophilous strain of high alcoholforming ability that ferments wort containing $13-14.5 \%$ alcohol by volume is obtained. Correspondingly, the yield of alcohol is increased by $1.9 \mathrm{dal} / \mathrm{Mt}$ of raw materials, the consumption of technological steam for the distillation of the wort is reduced by $6 \mathrm{~kg} / \mathrm{dal}$ the use of the artesian water for a batch preparation being also less. The application of new technological solutions can reduce the cost of the final product, namely ethyl alcohol rectified by $10-15 \%$, and promote solving the problem of utilization of the filtrate of the grain stillage [5].

In the dairy industry, the proper course of the enzymatic process is a prerequisite for obtaining safe and quality dairy products. In this respect, the spread of bacteriophages is a serious danger to production. In order to determine the strategy to combat phagolysis, a study was made of the biological properties of bacteriophages of lactic streptococci, as well as the ways of spreading phage infection in the production facilities, and the ways to prevent the said infection are suggested.

The strategic direction in solving the problems of the food industry is the creation of non-waste technologies for the processing of agricultural raw materials and the ecologization of production with the production of alternative fuels (bioethanol, biogas) and organic fertilizers. One of the directions of the innovative development of the food industry is the development of scientists of the Institute for the diversification of sugar beet production, since in the context of the aggravation of the problem of supplying energy to Ukraine and reducing the demand for white beet sugar, it is appropriate to speed up the production of bioethanol based on sugar beet. Traditional for Ukraine is the production of bioethanol from the waste of sugar beet production - molasses, but it can also be produced from intermediate products of processing sweet root crops: beet (diffusion) juice, sugar syrup, green molasses and the like. The use of intermediate products for the production of bioethanol according to the scheme developed by the scientists of the Institute makes it possible to balance the needs of Ukraine in sugar and to preserve and develop land areas for the cultivation of sugar beets, which is important both in terms of crop rotation and ecological.

According to calculations, energy efficiency (the ratio of energy received to spent) of production of bioethanol from sugar beet, taking into account their cultivation, is $173 \%$. The output of bioethanol from 1 hectare of sugar beet is greater than that of wheat -2.5 , potatoes -2.0 , corn -1.5 times. In addition, bioethanol due to the high content of organic compounds, increases the octane number and prevents the exfoliation of gasoline/alcohol mixtures. The production of bioethanol from sugar beet requires $25 \ldots 30 \%$ less energy consumption than from that of grain, since it does not require malt and enzyme preparations, and the intermediate products of sugar production can be fed for fermentation in a dissolved and heated state [6].

In conditions of excess capacity of production of alcohol for food purposes, the strategic task of developing the alcohol industry is the creation of an organizational structure for the production of bioethanol and biogas based on the capacities of distilleries that are not involved in the production of food alcohol. Technical and technological improvement of production, its diversification and increasing the depth of processing of raw materials on the basis of innovative technologies will help increase the profitability of enterprises in the industry and increase revenues to budgets of all levels.

Modern production of bioethanol is based on technologies of hydrolysis and fermentation of starchcontaining raw materials of the nutritional value. Aiming at expanding the raw material base and reducing the cost of bioethanol, it is advisable to use cellulose, the source of which is non-starch polysaccharides of cereals and stems of various plant raw materials. Previous studies carried out at the Institute have developed a technological regime for the dissolution of lignin in stalks of wheat straw, post harvest harvested corn and stalks of sugar sorghum by acid hydrolysis using an organic solvent - ethyl alcohol and further fermentolysis of delignified cellulose with enzyme preparations and fermenting obtained sugars into ethyl alcohol. 
Most food processing enterprises are mainly oriented to the production of a single type of products. Previous scientific developments have not solved the problem of integrated use of agricultural raw materials and waste production as a source of secondary raw materials and energy. Under such conditions, the competitiveness of the product decreases in terms of quality and value. To date, scientists of the Institute have developed technological solutions for the complex processing of corn with the release of corcules, corn groats and bioethanol, processing of post-alcohol stillage into concentrated or dry feed products, biogas, etc. With a deep processing of $1 \mathrm{Mt}$ of corn according to the developed scheme at domestic enterprises with production in accordance with the norms for the output of cereals, flour, oil, meal, corcules, mixed fodder, starch, glucose molasses, bioethanol, biogas and their sale, you can get an approximate income of up to 9 thousand UAH, that is, the Ukrainian producers, depending on the ratio of products, can get approximately an income more than twice as much as from grain exports. The technology of food syrup from sugar sorghum is developed, which provides for the complex use of raw materials to produce sorbents, bioethanol, highly purified cellulose and solid fuel. Scientific development is at the stage of industrial introduction [7].

In the current market conditions, industrial food production is directly related to the introduction of modern quality management and safety management systems. An integrated approach to food safety in the HACCP system involves considering the sequence of all stages and processes - from product creation to its final consumption. The plan is prepared in accordance with the conditions of the specific enterprise; however, the methods of control and testing, control of test equipment, product and system audits remain mandatory tools that are used on the way to quality assurance. Therefore, the development of a modern database of normative and technical documentation, methods of control, determination of their accuracy are important components of scientific support for the production of high-quality and safe products. Validation of the method of quantitative determination of urea content in milk by absorption spectrophotometry method in the variant of using additions method without the need to plot a calibration curve and to fulfill complicated calculations was fulfilled, which allowed to significantly accelerate the analysis process, reduce the time and materials consumption [8]. A high correlation between the values of the ratio of stable isotopes of Carbon ${ }^{13} \mathrm{C} /{ }^{12} \mathrm{C}\left({ }^{13} \mathrm{C}\right.$ ) in the protein phase of milk and its urea content had been proved, which made it possible to clearly distinguish between specimens originating from organic farms with high and low intensity types of farming. A not overlapping range of ${ }^{13} \mathrm{C}$ values and urea content values of these types of milk was recorded (5.5\%o and $4.65 \mathrm{mg} / 100 \mathrm{~g}$ correspondingly through the stall period and $3.40 \%$ o and $10.77 \mathrm{mg} / 100 \mathrm{~g}$ correspondingly for the grazing period) [9].

A significant component of the Institute's work is cooperation with the sectoral formations of food producers [10]. It should be noted in particular that in recent years the institute's position on the coordination and interaction between institutions of different subordination has been strengthened, for the effective use of common scientific potential in solving urgent problems of agro-industrial production.

\section{Conclusions}

Effective functioning of domestic food industry is possible only on the basis of interaction of science and entrepreneurship.

The developed technologies and proposed technological solutions are of great importance for the food industry and can significantly increase its revenue part. The legislative and regulatory framework shall be improved this ensuring the functioning of the food complex on the basis of a fuller use of the capabilities of domestic multi-profile production to meet the needs of the domestic market, to substitute imported foods, to increase the share of products with a high degree of processing.

\section{References}

1. Borsoliuk L.M., Voitsekhivska L.I., Verbytskyi S.B., Lyzova V.Iu. (2017). Doslidzhennia fizykokhimichnykh i tekhnolohichnykh vlastyvostei roslynnoi syrovyny u skladi funktsionalnykh pashtetnykh produktiv. [Investigation of physicochemical and technological properties of vegetative raw materials in functional pesto products]. Prodovolchi resursy. Zbirnyk naukovykh prats. Vyp. 9. P.126 - 135. [In Ukrainian]. 
2. Hrushetskyi R.I., Khomichak L.M., Hrynenko I.H. (2014). Oderzhannia synbiotyka na osnovi inulinu ta bifidobakterii. [Preparation of synbiotic based on inulin and bifidobacteria]. Prodovolchi resursy. Zbirnyk naukovykh prats. Vyp. 9. P. 18 - 22. [In Ukrainian].

3. Yeresko H.O., Yeroshenko S.I., Mykhailyk V.O., Parniakov O.S. (2016). Fazovi perekhody v zhyrakh ta zhyrovykh kompozytsiiakh. [Phase transitions in fats and fat compositions]. Prodovolchi resursy. Zbirnyk naukovykh prats. Seriia: Tekhnichni nauky. Vyp. 2. P. 111 - 119. [In Ukrainian].

4. Sychevskyi M.P., Orliuk Yu.T. (2016). Reolohichni kharakterystyky bilkovo-syrovatkovoi sumishi. [Rheological characteristics of the protein-whey mixture]. Naukovyi visnyk LDAVM im. Hzhytskoho. T. 18 (2). No 2 (68). P. 95 - 98. [In Ukrainian].

5. Sychevskyi M.P., Oliinichuk S.T., Danilova K.O. (2016). Biosyntez etylovoho spyrtu riznymy rasamy drizhdzhiv $v$ umovakh pidvyshchenoi kontsentratsii susla. [Biosynthesis of ethyl alcohol by different races of yeast in conditions of increased concentration of wort]. Naukovi dopovidi NUBIP Ukrainy. No 5 (62). [In Ukrainian].

6. Sychevskyi M.P., Khomichak L.M., Oliinichuk S.T. et al. (2013). Shliakhy dyversyfikatsii tsukroburiakovoho vyrobnytstva. [Ways of diversification of sugar beet production]. Tsukor Ukrainy. No 3 (87). P. 30 - 35. [In Ukrainian].

7. Hryhorenko N.O., Shtanheiev V.O., Khomichak L.M. (2016). Nova perspektyvna syrovyna dlia tsukrovoi haluzi - sorho tsukrove (Sorghum saccharatum (L.) Pers.). [A new promising raw material for the sugar industry is sugar sorghum (Sorghum saccharatum (L.) Pers.)]. Prodovolchi resursy. Zbirnyk naukovykh prats. P. 153 - 156. [In Ukrainian].

8. Zhukova Ya., Petrov P., Klimenko L. (2017). Express Method Of Quantitative Determination Of Urea In Milk. Товари і ринки. No 2. P. $17-35$.

9. Zhukova Ya., Petrov P., Demikhov Yu., Mason A., Korostynska O. (2017). Milk Urea Content and 13C as Potential Tool for Differentiation of Milk from Organic and Conventional Low- and High-Input Farming Systems. Turkish Journal of Agriculture - Food Science and Technology. V. 5, No 9. P. $782-786$.

10. Kovalenko O.V. (2015). Innovatsii ta biznes u kharchovii promyslovosti: monohrafiia. [Innovation and Business in the Food Industry: Monograph]. Kyiv: NNTs «IAE», 298 p. [In Ukrainian]. 